\title{
Research
}

\section{Myo-inositol effects in women with PCOS: a meta-analysis of randomized controlled trials}

\author{
Vittorio Unfer ${ }^{1}$, Fabio Facchinetti ${ }^{2}$, Beatrice Orrù ${ }^{3}$, Barbara Giordani ${ }^{3}$ and \\ John Nestler ${ }^{4}$
}

${ }^{1}$ Health Department, UniPoliSi - Institut des Etudes Universitaires, Disentis, Switzerland ${ }^{2}$ Mother-Infant Department, University of Modena and Reggio Emilia, Modena, Italy ${ }^{3}$ Medical Affairs Department, Lo.Li. Pharma, Rome, Italy

${ }^{4}$ Departments of Medicine and Obstetrics and Gynecology, Virginia Commonwealth University, Richmond, Virginia, USA

\author{
Correspondence \\ should be addressed \\ to $V$ Unfer \\ Email \\ vunfer@gmail.com
}

\begin{abstract}
Myo-inositol (MI) supplementation in women with polycystic ovary syndrome (PCOS) has been evaluated over the last years. Many hormonal and reproductive impairments associated with this disorder seem relieved by the supplement. The objective of the meta-analysis was to assess the effects of $\mathrm{MI}$ alone or combined with D-chiro-inositol (DCI) on the endocrine and metabolic abnormalities of women with PCOS. Literature was retrieved from selected databases, MEDLINE, EMBASE, PubMed and Research Gate (up to November 2016). Only randomized controlled trials (RCTs) investigating the effects of MI alone or combined with DCl were reviewed. Nine RCTs involving 247 cases and 249 controls were included. Significant decreases in fasting insulin $(S M D=$ $-1.021 \mu \mathrm{U} / \mathrm{mL}, 95 \% \mathrm{Cl}:-1.791$ to $-0.251, P=0.009)$ and homeostasis model assessment (HOMA) index ( $\mathrm{SMD}=-0.585,95 \% \mathrm{Cl}:-1.145$ to $-0.025, P=0.041$ ) were identified after MI supplementation. The trial sequential analysis of insulin meta-analysis illustrates that the cumulative $z$-curve crossed the monitoring boundary, providing firm evidence of the intervention effect. A slight trend toward a reduction of testosterone concentration by $\mathrm{MI}$ with respect to controls was found (SMD $=-0.49,95 \% \mathrm{Cl}:-1.072$ to $0.092, P=0.099$ ), whereas androstenedione levels remained unaffected. Throughout a subgroup's metaanalysis, a significant increase in serum SHBG was observed only in those studies where $\mathrm{MI}$ was administered for at least 24 weeks $(\mathrm{SMD}=0.425 \mathrm{nmol} / \mathrm{L}, 95 \% \mathrm{Cl}: 0.050-0.801$, $P=0.026$ ). These results highlight the beneficial effect of $\mathrm{MI}$ in improving the metabolic profile of women with PCOS, concomitantly reducing their hyperandrogenism.
\end{abstract}

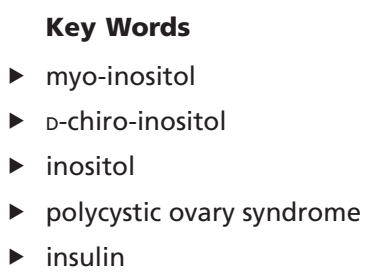

Endocrine Connections (2017) 6, 647-658

\section{Introduction}

Myo-inositol (MI) is one stereoisomer of a $\mathrm{C}_{6}$ sugar alcohol that belongs to the inositol family (1). It is the precursor of inositol triphosphate, acting as an intracellular second messenger and regulating a number of hormones such as thyroid-stimulating hormone, follicle-stimulating hormone (FSH) and insulin (2).

MI and D-chiro-inositol (DCI), another stereoisomeric form of inositol, balance in different ways some metabolic
() 2017 The authors Published by Bioscientifica Ltd deregulations concurring with insulin resistance (IR) (3): MI-derived phosphoinositol-3-phosphate (PIP3) enhances glucose transport inside the cells through the stimulation of GLUT4 translocation to the cell membrane. Its derivative inositolphosphoglycan (MI-IPG) plays a pivotal role in downregulating the release of free fatty acids (FFA) from adipose tissues, hindering the enzyme adenylate cyclase. Indeed, FFA are known to reduce glucose

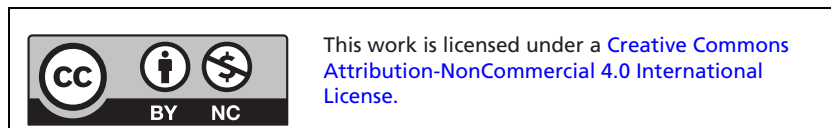


disposal, causing IR and increased triglyceride synthesis. DCI upregulates pyruvate dehydrogenase leading to the production of ATP by the Krebs' cycle. MI and DCI promote glycogen synthase, inducing glucose conversion to glycogen stored inside cells. MI modulates the activation of glucose transporters and glucose utilization, and glycogen synthesis takes place under the control of DCI. This molecule on the ovary regulates the insulininduced androgen synthesis, whereas MI regulates glucose uptake and FSH signaling (1).

In view of its recognized insulin-sensitizing activity, MI has been used to prevent and/or treat a number of metabolic disorders related to IR, such as the metabolic syndrome $(4,5)$, gestational diabetes mellitus $(6,7,8,9$, $10)$ and the polycystic ovary syndrome (PCOS) $(11,12,13)$.

PCOS is a heterogeneous endocrine, reproductive and metabolic disorder, affecting at least $5-10 \%$ of the total population of reproductive-age women, worldwide (14). Independently of body habitus (15), women with PCOS manifest a 50-70\% incidence of IR, resulting in a compensatory hyperinsulinemia, which derives many of the phenotypic features of this disease. PCOS encompasses a broad spectrum of biochemical/clinical signs and symptoms such as irregular menstrual cycles, polycystic ovaries, acne, overweight, androgen excess with consequent hirsutism and as aforementioned IR $(16,17)$. It is also associated with several long-term health consequences, including obesity $(18,19)$, infertility $(20)$, obstetric complications (21), type 2 diabetes $(22,23,24)$, cardiovascular disease $(24,25,26,27)$, psychological distress (28) and ostensibly mood disorders (29, 30). A meta-analysis also reported the association between women with PCOS and cancer of the endometrium and ovarian cancer (31).

It is noteworthy that improvement of IR and reduction of circulating insulin are key therapeutic targets in PCOS (32), enhancing fertility and reducing the lifelong risk for type 2 diabetes and early cardiovascular disease. Besides metformin, MI is now considered as a further insulinsensitizing supplement which could benefit women with PCOS $(33,34)$. Exercises and a healthy nutritional lifestyle have widely been gathering attention in the management of PCOS. Although robust data should be addressed in further investigation, a study showed beneficial effects in patients affected by obesity and type 2 diabetes following either a Mediterranean or ketogenic diet (35).

While there are numerous uncontrolled reports, the effects of supplementation with MI in PCOS have also been evaluated in randomized controlled trials (RCTs). A protocol critically reviewing the existing literature has been published within the Cochrane Reviews (36). The present meta-analysis would identify RCTs of supplementation with MI alone or combined with DCI in PCOS, with the aim to assess the effectiveness of such treatments in restoring the metabolic and endocrine profiles.

\section{Materials and methods}

\section{Search strategy and data sources}

We performed a literature search of MEDLINE, EMBASE, PubMed and Research Gate for studies published in any language up to November 2016. We used the following combination of medical subject headings, terms and free text words: 'inositol', 'MI', 'DCI', 'PCOS' and 'IR'. Only RCTs evaluating the supplementation of MI alone or in association with DCI in women with PCOS were eligible. In addition, reference lists of published reviews were reviewed in order to identify additional eligible studies. We followed the PRISMA checklist for meta-analysis (38).

\section{Inclusion and exclusion criteria}

Articles were critically reviewed for their eligibility in the meta-analysis by the two of us (B O and F F). Among all the collected articles, RCTs were identified by reading titles, abstracts and study design to select relevant studies for inclusion/exclusion criteria. Inclusion criteria restricted the search to: (a) the population of interest was women with PCOS, (b) the intervention was MI with or without DCI, (c) assessment of fasting insulin concentrations, HOMA index, testosterone, androstenedione and/or sex hormonebinding globulin (SHBG) plasma levels. Exclusion criteria were: (a) articles describing MI treatments in combination with other drugs/supplements, (b) duplicate publications, and duplicates on different database, (c) review papers and (d) animal or cell culture studies.

\section{Outcomes of interest}

Primary outcomes: fasting insulin concentrations. Secondary outcomes: HOMA index, testosterone, androstenedione and SHBG plasma levels.

\section{Data extraction and quality evaluation}

The following data were extracted from the full text of selected studies and cross-checked by two researchers http://www.endocrineconnections.org
DOI: 10.1530/EC-17-0243
(๑) 2017 The authors Published by Bioscientifica Ltd
This work is licensed under a Creative Commons Attribution-NonCommercial 4.0 International License. 
(B O and F F): general characteristics of the study (first author's name, country where the study was conducted, study design, number of cases and controls, body mass index, inclusion/exclusion criteria, lifestyle changes, type and duration of treatment) and results (means and S.D./s.e. for each outcome after intervention from treatment vs control). The quality of reports was evaluated according to the methods recommended by the Cochrane Handbook 5.0.2. (37), including assessments of the randomization process, allocation concealment, blinding, selection criteria, baseline characters and withdrawal/dropouts.

\section{Statistical analysis}

The effect size was measured as the standardized mean difference (SMD) obtained as Hedges' g. An SMD less than 0 was considered as a positive size effect for outcomes, such as fasting serum insulin, HOMA and serum testosterone and androstenedione concentrations; an SMD greater than 0 was considered as a positive size effect for the serum SHBG outcome. The heterogeneity analysis of intervention was performed by the Cochran's $Q$ test and the $I^{2}$ statistic, using a $P$ value $=0.10$. In order to account for heterogeneity across studies, the Der Simonian and Laird random effect model was used to obtain the pooled estimates and their 95\% confidence intervals (CIs). To examine a potential source of variation, subgroup meta-analyses were performed according to treatment duration, i.e. 12-16 weeks or 24 weeks. Forest plots were used to visually show the results of the analyses performed. Meta-analysis was evaluated by the use of Stata Statistical Software: Release 12 (College Station, TX, USA: StataCorp LP). Results were considered statistically significant when the twosided $P$ value was $<0.05$.

\section{Trial sequential analysis (TSA)}

The TSA was performed for the insulin outcome in order to confirm the result obtained in the traditional metaanalysis. The cumulative $z$-curve was calculated with a random effect model and the type I error $(\alpha)$ was set as $5 \%$ with a power of $80 \%$. The sequential monitoring boundaries were based on the O'Brien Flaming type alpha spending function and the heterogeneity correction was model-variance-based. The analysis was conducted with the use of TSA software 0.9.5.5 Beta (Copenhagen Trial Unit, Copenhagen, Denmark).

\section{Results}

\section{Literature search and characteristics of included studies}

The flow diagram of the meta-analysis is presented in Fig. 1 (38). In the initial search, 104 potentially relevant articles were identified, and 94 studies remained after removing duplicates. Through a preliminary screening, 76 records were excluded because they did not meet the inclusion/exclusion criteria. The remaining 18 articles were assessed for eligibility, and 9 articles which met the criteria were finally included in the meta-analysis. Studies were excluded for several reasons including (a) data of the outcome were unavailable or not expressed in the numerical form (39), (b) patients were treated with MI combined with other molecules such as multivitamin complex (40), lactoferrin and bromelin (41) or oral contraceptives pills (OCPs) (42), (c) menopausal women with metabolic syndrome $(4,5)$ and $(d)$ the study was a non-randomized design $(43,44,45)$.

Characteristics of the included studies are summarized in Table 1 . Studies were conducted in Italy $(46,47,48,49,50,51,52)$, Georgia (53) and Turkey (54) and were published between 2007 and 2016. Treatments

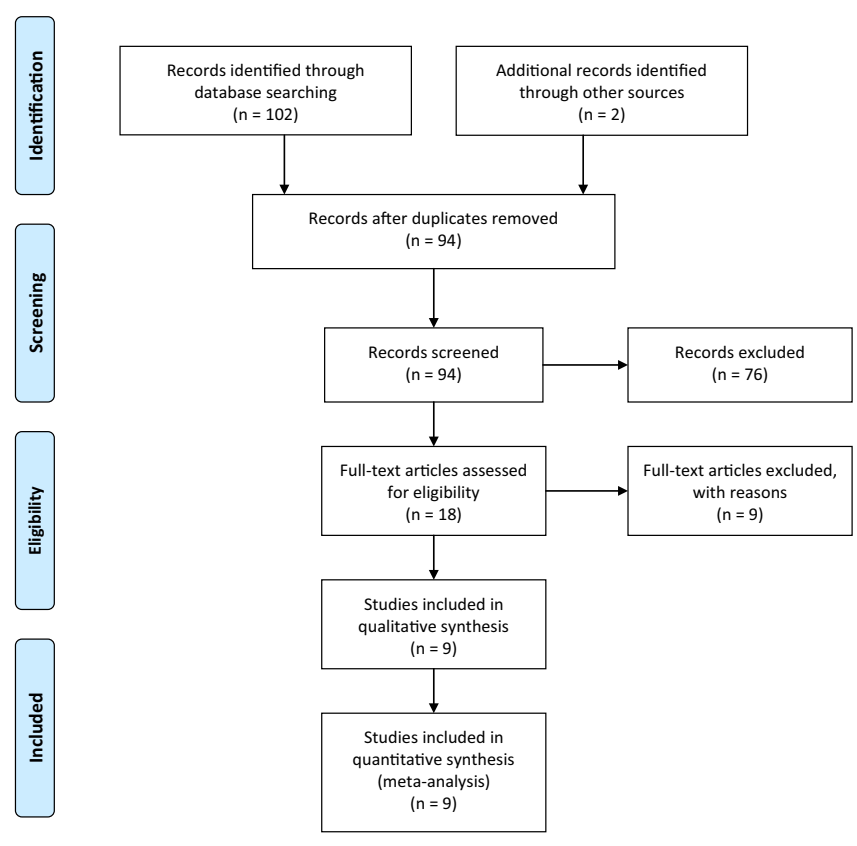

Figure 1

PRISMA (preferred reporting items for systematic reviews and metaanalyses) flow diagram of study selection (38). Reproduced under the terms of the Creative Commons Attribution License from Moher D, Liberati A, Tetzlaff J, Altman DG, The PRISMA Group. Preferred reporting items for systematic reviews and meta-analyses: the PRISMA statement. PLoS Medicine 20096 e1000097. (doi:10.1371/journal.pmed1000097)

This work is licensed under a Creative Commons Attribution-NonCommercial 4.0 International License. 


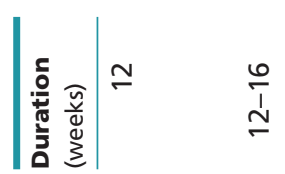

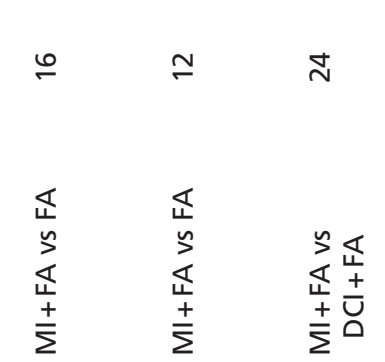

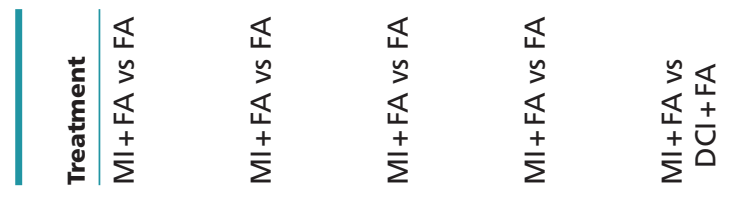

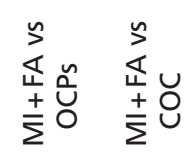

$\stackrel{4}{A}$

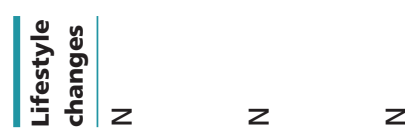

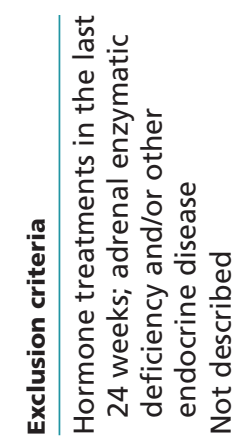

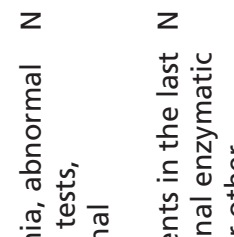

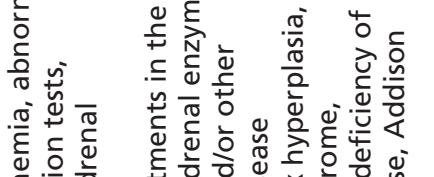

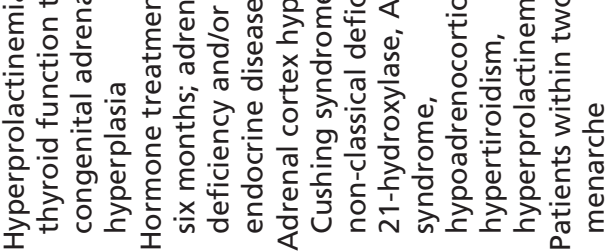

$z$

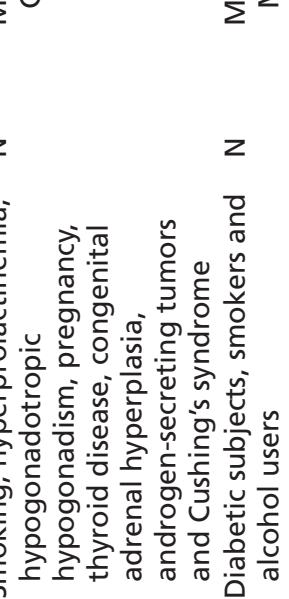

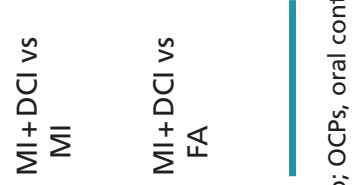

|

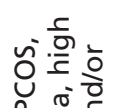

类

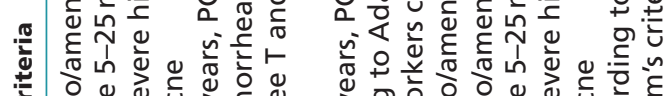

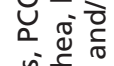

Oी

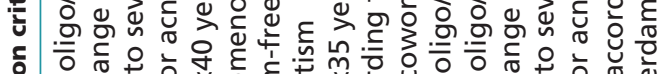

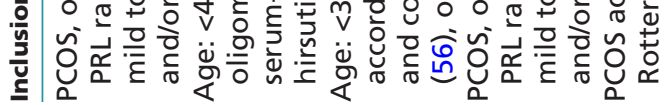

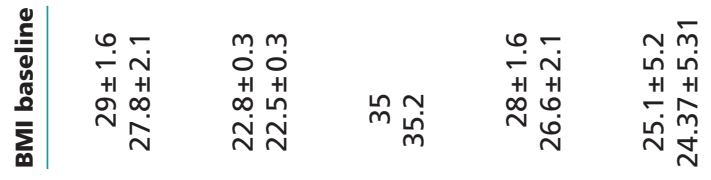

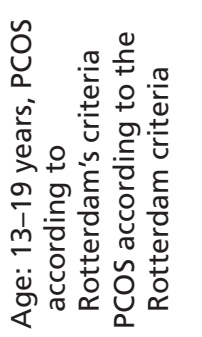

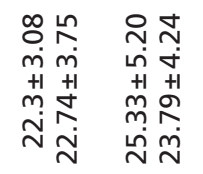

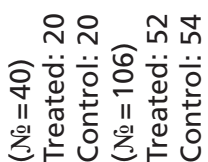

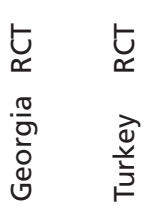

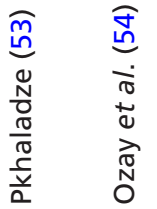

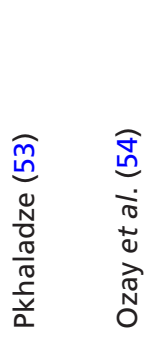

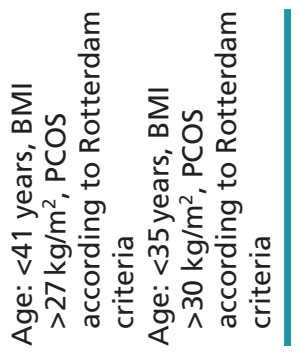

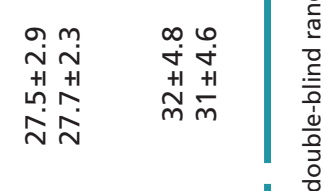

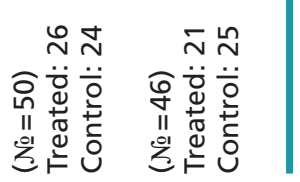

$\underset{\varpi}{\longleftarrow} \quad$

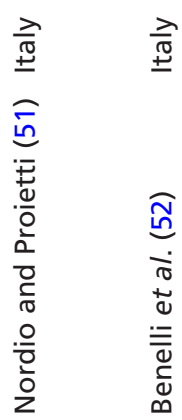

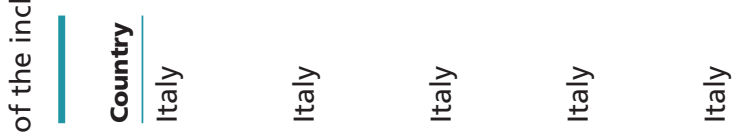

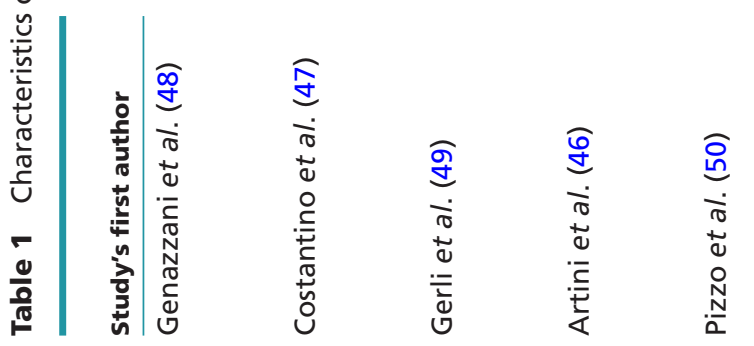

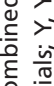


Table 2 Quality assessment of included trials.

\begin{tabular}{|c|c|c|c|c|c|c|}
\hline Study & Randomization & $\begin{array}{l}\text { Allocation } \\
\text { concealment }\end{array}$ & Blinding & $\begin{array}{l}\text { Selection } \\
\text { criteria } \\
\text { described }\end{array}$ & $\begin{array}{l}\text { Comparable } \\
\text { baseline }\end{array}$ & $\begin{array}{l}\text { Withdrawal dropout } \\
\text { described }\end{array}$ \\
\hline Genazzani et al. (48) & $\mathrm{M}$ & Unclear & $\mathrm{N}$ & $\mathrm{Y}$ & $\mathrm{Y}$ & Unclear \\
\hline Costantino et al. (47) & $\mathrm{M}$ & Unclear & Y, double-blind & $Y$ & $\mathrm{Y}$ & Unclear \\
\hline Gerli et al. (49) & Y, computer-generated & Unclear & Y, double-blind & $\mathrm{Y}$ & $\mathrm{Y}$ & $\mathrm{Y}$ \\
\hline Artini et al. (46) & Y, computer-generated & $\begin{array}{l}\text { Y, sealed } \\
\text { numbered } \\
\text { envelopes }\end{array}$ & Unclear & $\mathrm{Y}$ & $\mathrm{Y}$ & $\mathrm{Y}$ \\
\hline Pizzo et al. (50) & $\mathrm{M}$ & Unclear & Y, double-blind & $\mathrm{Y}$ & $\mathrm{Y}$ & Unclear \\
\hline Pkhaladze et al. (53) & $\mathrm{M}$ & $\mathrm{N}$ & $\mathrm{N}$ & Y & $\mathrm{Y}$ & Unclear \\
\hline Ozay et al. (54) & $\mathrm{Y}$ & Unclear & $\mathrm{N}$ & $\mathrm{Y}$ & $\mathrm{Y}$ & $\mathrm{M}$ \\
\hline Nordio and Proietti (51) & $\mathrm{M}$ & $\mathrm{N}$ & $\mathrm{N}$ & $\mathrm{Y}$ & $\mathrm{Y}$ & Unclear \\
\hline Benelli et al. (52) & $\mathrm{M}$ & Unclear & $\mathrm{N}$ & Y & $\mathrm{Y}$ & Unclear \\
\hline
\end{tabular}

Evaluation according to the methods recommended by the Cochrane Handbook 5.0.2 (37).

$\mathrm{M}$, the method was mentioned, but there was not detailed description; $\mathrm{N}$, the method was not used in the study; Unclear, no relevant information was found in the study; $Y$, the method was reported with detailed description.

administered were $\mathrm{MI}+$ folic acid (FA) vs FA $(46,47,48,49)$, $\mathrm{MI}+\mathrm{FA}$ vs $\mathrm{DCI}+\mathrm{FA}(50), \mathrm{MI}+\mathrm{DCI}$ vs $\mathrm{MI}$ (51), $\mathrm{MI}+\mathrm{DCI}+\mathrm{FA}$ vs FA (52), and MI+FA vs OCPs $(53,54)$. The daily dose of MI supplementation ranged from $1.1 \mathrm{~g}$ to $4 \mathrm{~g}$, and the durations of treatment ranged from 12 to 24 weeks. Either Rotterdam (55) or Adams and coworkers diagnostic criteria (56) were applied for the diagnosis of PCOS. The overall methodological study quality is summarized in Table 2 .

\section{The meta-analysis}

In the nine selected studies, a total of 247 women with PCOS received MI alone or combined with FA or DCI, and 249 women received FA or other treatments (i.e. DCI, OCPs). The overall SMD estimated from seven studies showed a significant decrease in fasting insulin in PCOS women who received $\mathrm{MI}$ compared to those who received FA or other treatments $(\mathrm{SMD}=-1.021 \mu \mathrm{U} / \mathrm{mL}, 95 \% \mathrm{CI}:-1.791$ to $-0.251, P=0.009$ ) (Fig. 2). Considerable heterogeneity among studies was found $\left(Q=63.85, d f=6, I^{2}=90.6 \%\right.$, $P<0.001)$. Evidence of an MI effect was also identified for the HOMA index which decreased with treatment in the MI group compared to controls ( $\mathrm{SMD}=-0.585$, 95\% CI: -1.145 to $-0.025, P=0.041$ ) (Fig. 3). Again, high heterogeneity across studies was found $(Q=37.84, d f=6$, $\left.I^{2}=84.1 \%, P<0.001\right)$.

Similarly, seven trials reporting the effect of MI on serum testosterone revealed substantial heterogeneity among studies $\left(Q=37.65, d f=6, I^{2}=84.1 \%, \quad P<0.001\right)$ (Fig. 4). A slight trend toward a reduction of testosterone

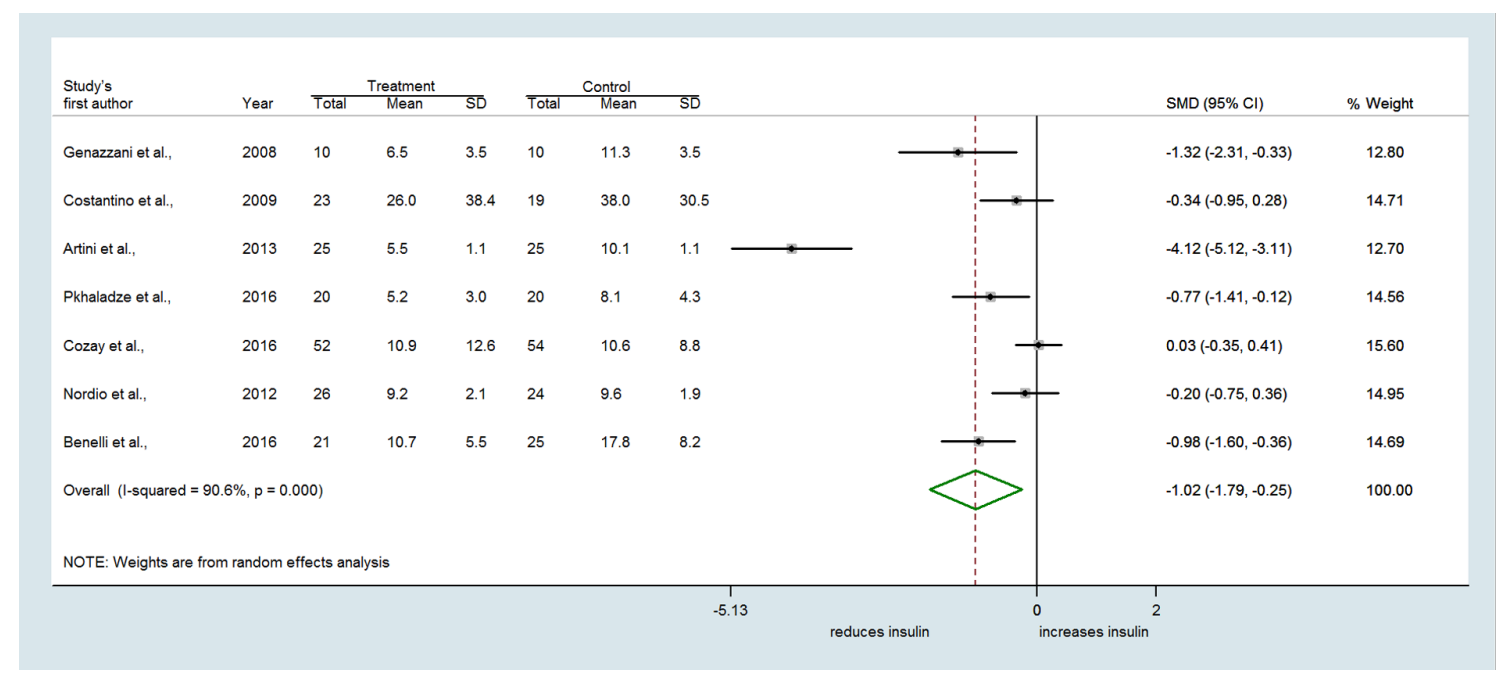

Figure 2

Forest plot showing effect sizes (standardized mean difference (SMD), 95\% confidence interval (CI)) for fasting insulin in women with PCOS.

\begin{tabular}{|lr} 
http://www.endocrineconnections.org & ○ 2017 The authors \\
DOI: $10.1530 /$ EC-17-0243 & Published by Bioscientifica Ltd
\end{tabular}

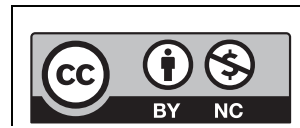

This work is licensed under a Creative Commons Attribution-NonCommercial 4.0 International License. 


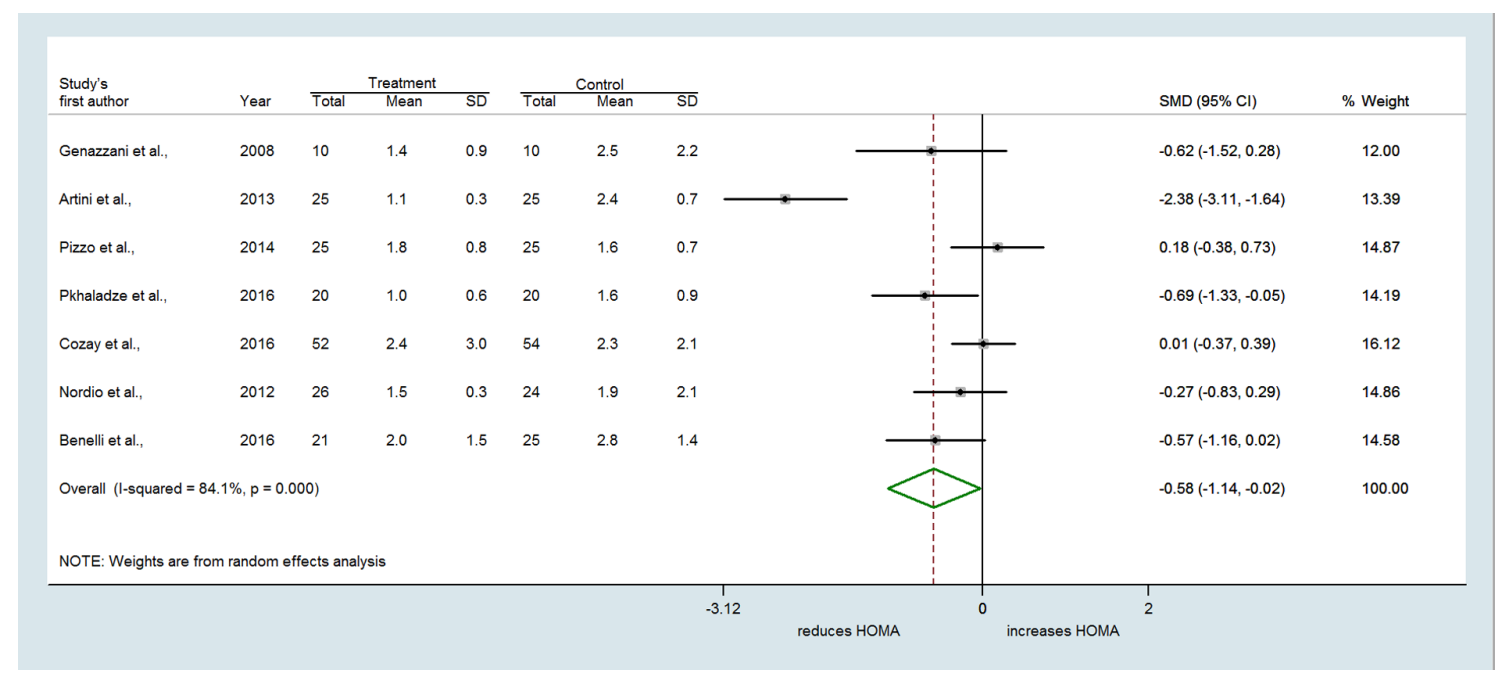

Figure 3

Forest plots showing effect sizes (SMD) for HOMA in women with PCOS.

concentrations by MI with respect to controls was found $(\mathrm{SMD}=-0.482, \quad 95 \% \mathrm{CI}:-1.052$ to $0.088, \quad P=0.097)$ (Fig. 4). Conversely, no difference between treatments was observed either for androstenedione $(\mathrm{SMD}=-0.097 \mathrm{ng} / \mathrm{mL}$, 95\% CI: -0.499 to $0.305, P=0.635$ ) (Fig. 5) or SHBG levels $(\mathrm{SMD}=0.166 \mathrm{nmol} / \mathrm{L}, 95 \% \mathrm{CI}:-0.247$ to $0.580, P=0.430)$ (Fig. 6).

A subgroup analysis was undertaken stratifying the studies by treatment duration. Treatment of MI up to 16 weeks had no significant effect on SHBG levels compared to controls $(\mathrm{SMD}=-0.016 \mathrm{nmol} / \mathrm{L}$, 95\% CI: -0.621 to $0.589, P=0.958$ ) (Fig. 6). However, MI supplementation up to 24 weeks revealed a significant increase in SHBG levels compared to other treatments $(\mathrm{SMD}=0.418 \mathrm{nmol} / \mathrm{L}, \quad 95 \%$ CI: $0.049-0.786, \quad P=0.026)$ (Fig. 6). After stratification, heterogeneity was substantial among RCTs lasting $12-16$ weeks $(Q=17.98, d f=3$, $\left.I^{2}=83.3 \%, P<0.001\right)$, whereas it was much lesser among those of longer duration $\left(Q=2.49, d f=2, I^{2}=19.6 \%\right.$, $P=0.288)$.

\section{Results of TSA}

The $z$-curve after the fourth trial crossed the sequential monitoring boundary providing firm evidence of an effect of MI on fasting insulin compared to controls (Fig. 7).

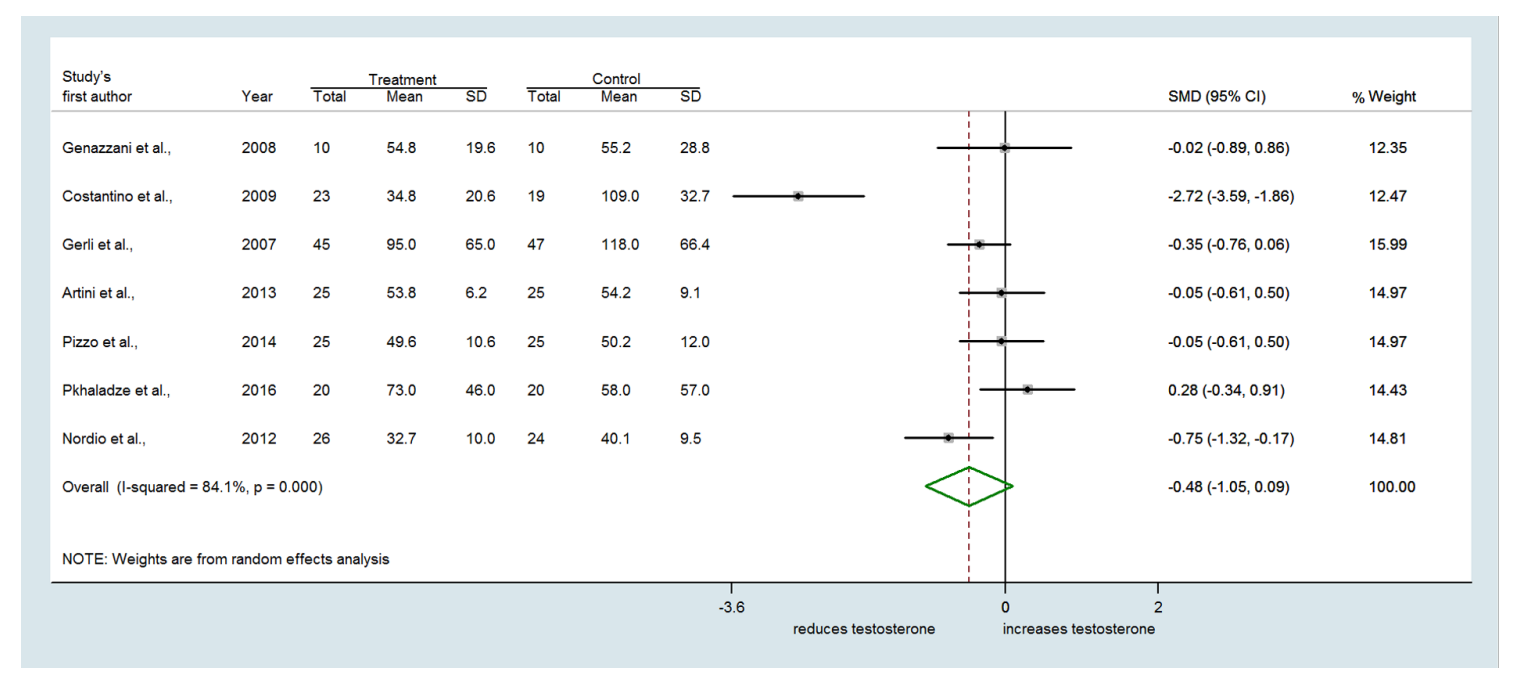

Figure 4

Forest plots showing effect sizes (SMD) for testosterone in women with PCOS.

\begin{tabular}{lr}
\hline http://www.endocrineconnections.org & ○ 2017 The authors \\
DOI: $10.1530 /$ EC-17-0243 & Published by Bioscientifica Ltd
\end{tabular}




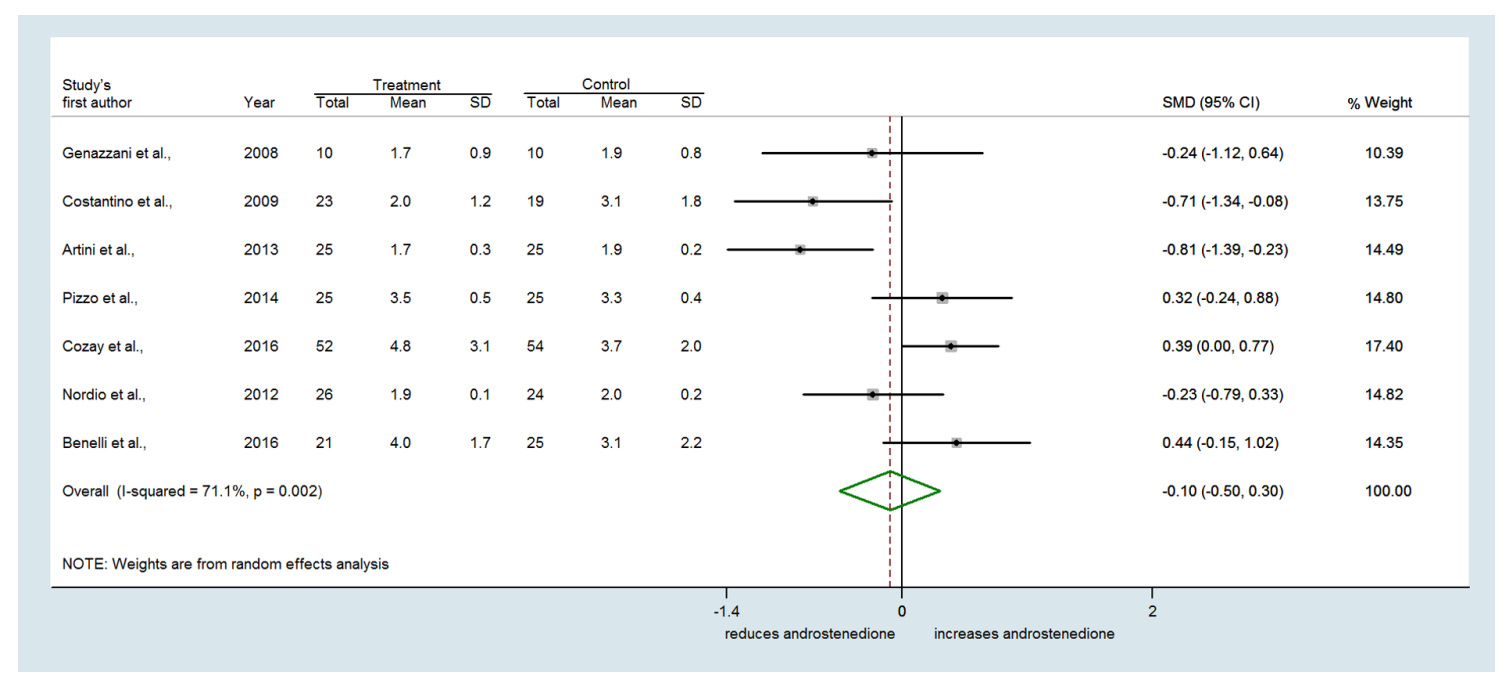

Figure 5

Forest plots showing effect sizes (SMD) for androstenedione in women with PCOS.

\section{Discussion}

The current meta-analysis highlights the beneficial effect of inositol(s) supplementation, namely MI in improving the metabolic profile of PCOS patients. Indeed, grouping the nine eligible studies, results revealed differences in the treatment effect on fasting serum insulin and on the HOMA index, both of them being significantly decreased after MI supplementation. In this study, through the use of TSA, it was illustrated that the findings on the primary outcome are conclusive. Less clear changes could be demonstrated on androgenic hormones. Circulating androstenedione levels were unaffected by MI, while a trend toward a decrease of total testosterone occurred. Moreover, a significant increase of serum SHBG compared to other treatments was reported only in those trials which supplemented inositol(s) for at least 24 weeks.

These findings were limited by differences in the inclusion criteria of the studies, non-uniform definitions of PCOS and diversity in the components of the intervention such as dose and duration. All these factors therefore explain the high heterogeneity statistically demonstrated along with the effects.

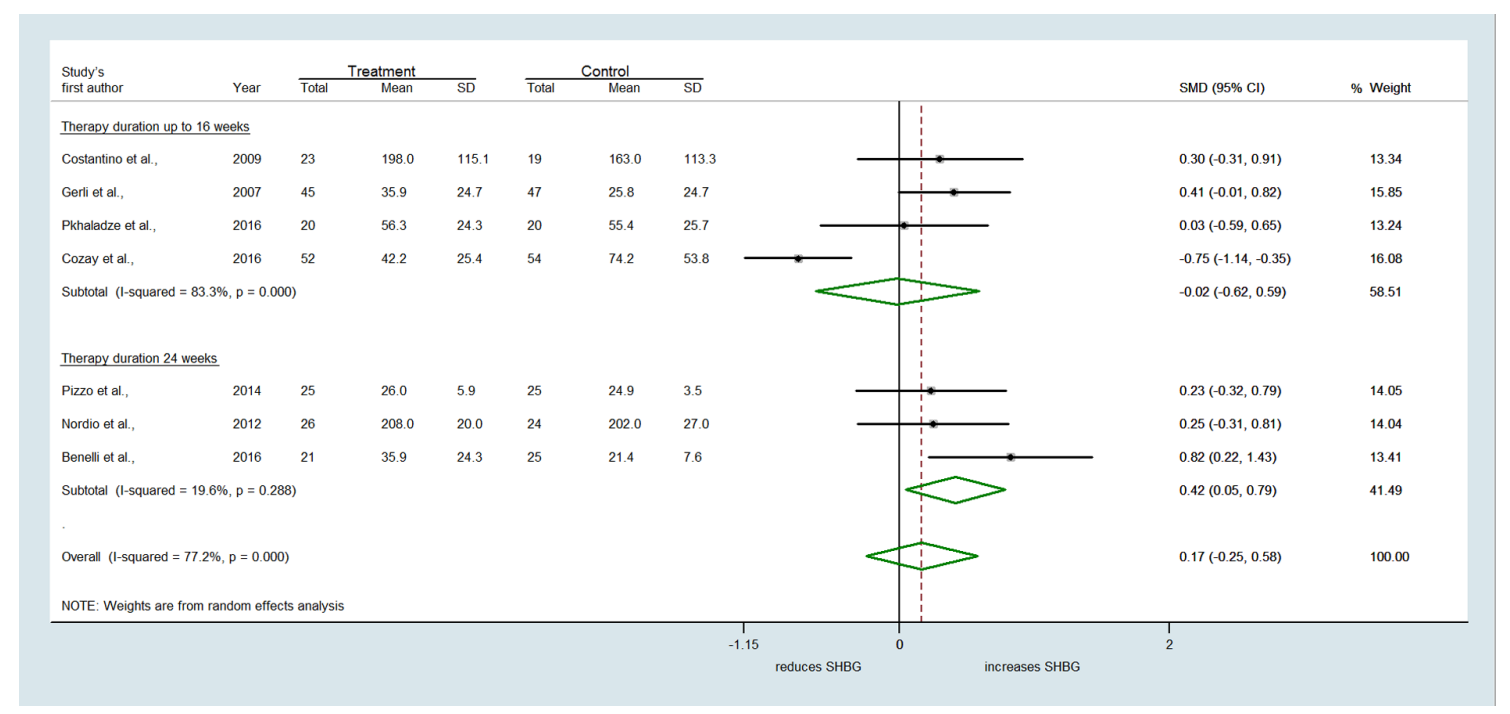

Figure 6

Subgroup meta-analysis for SHBG stratifying the studies by treatment duration (MI up to 16 weeks or 24 weeks).

http://www.endocrineconnections.org DOI: 10.1530/EC-17-0243 (c) 2017 The authors Published by Bioscientifica Ltd This work is licensed under a Creative Commons
Attribution-NonCommercial 4.0 International License. 


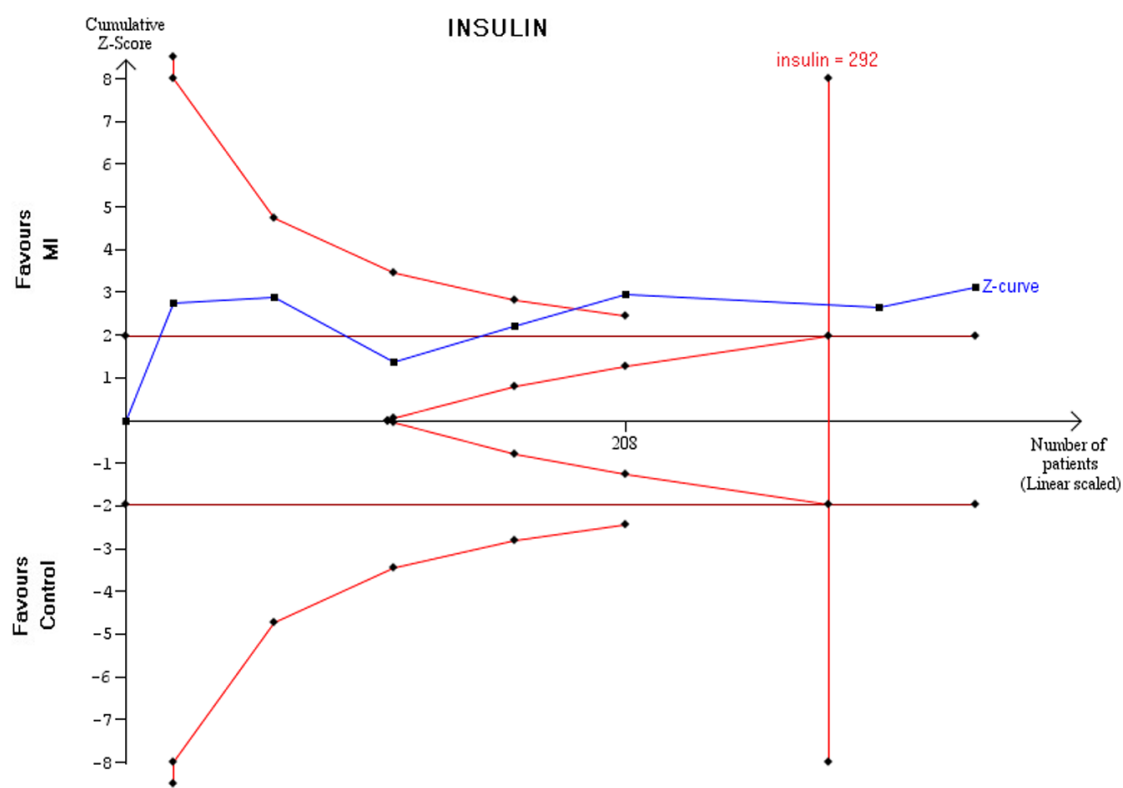

Figure 7

Trial sequential analysis on insulin outcome.
MI is the most abundant form of inositol in humans. It can turn into various derivatives through either epimerization, phosphorylation or methylation of its hydroxyl groups. The NAD/NADH epimerase, an insulindependent enzyme, converts MI into DCI, depending on the specific needs of the tissue for these two molecules $(57,58)$. Indeed, different tissues have a typical conversion rate and consequently show different MI/DCI ratios (for instance, in the ovary, it is 100:1) (59). The epimerase activity is reduced in the tissues of type 2 diabetic rats (60). There is evidence that MI to DCI conversion rate is impaired in PCOS patients due to IR; this aberration is exacerbated when having first-degree diabetic relatives $(41,58)$. The pathology itself or the familial predisposition negatively affects the epimerase activity, thus increasing IR and compensatory hyperinsulinaemia (61). Indeed, lower levels of DCI reduce the availability of IPGs triggering the onset of IR $(62,63)$. Baillargeon and coworkers have demonstrated an increase of DCI urinary excretion in PCOS women compared to normal controls accompanied by a decrease of plasma DCI concentrations $(11,64)$. However, no difference was found in MI concentration (64). It has been shown how administration of small DCI doses can restore insulin sensitivity and improve the hormonal pattern in obese hyperinsulinemic PCOS patients and even more if having diabetic relatives $(41,61)$. This specific effect might be due to its recognized insulin-sensitizing action at the systemic level. Therefore, the administration of DCI along with MI might have a greater beneficial effect when the epimerase conversion is impaired in insulin-resistant tissues to compensate for the low endogenous DCI synthesis and its excessive urinary excretion, as well as ensuring the required tissue content of DCI derivatives. Ovaries, differently from other tissues, never become insulin-resistant $(65,66,67)$. From this observation, it has been speculated that PCOS patients with hyperinsulinemia may have an accelerated MI to DCI epimerization, resulting in an overproduction of DCI and consequently an MI deficiency in the ovary $(68,69)$. The well-known 'DCI paradox' hypothesizes that only MI has a beneficial effect on the ovary (70). This theory has been later confirmed by a recent study showing that the oocyte quality and ovarian response have been progressively worsened by the increased dosage of DCI (71). Therefore, DCI supplementation alone is not recommendable for several reasons: (a) high doses of DCI/day have been considered toxic to ovaries and oocyte maturation (71); (b) DCI is not converted into MI; therefore, the specific action exerted by the last one would be lost; (c) MI and MI-IPG deficiencies are correlated with many IR conditions. Since MI competes with glucose for cellular transporters, a low MI intracellular uptake and increased urinary loss of MI may lead to high blood glucose levels. It can be supposed that adequate MI intake and body storages might derive the epimerase by substrate mass action inducing DCI synthesis. This agrees with the clinical evidence that reported the beneficial effect exerted by MI and DCI combined at 40:1 ratio in PCOS patients $(51,52)$. Further investigations might be required as also suggested by other researchers (72).

Hyperinsulinemic IR has been shown to play a pivotal pathogenic role in the endocrine and metabolic http://www.endocrineconnections.org DOI: 10.1530/EC-17-0243
(C) 2017 The authors Published by Bioscientifica Ltd
This work is licensed under a Creative Commons Attribution-NonCommercial 4.0 International License. 
(

abnormalities of PCOS $(73,74)$. The improvement of insulin sensitivity and the reduction of serum insulin demonstrated by MI supply are of paramount importance for ameliorating the clinical features of women with PCOS (75). The CIs for the selected studies were relatively narrow and displayed effect sizes that may be clinically relevant. These findings, therefore, support the practice of treating PCOS women with MI, either alone or in combination with DCI, to improve their endocrine and metabolic profiles.

Treatment duration seems crucial, as far as androgen profile is concerned. This agrees with the previous observation on acne, whose improvement with MI required at least 6 months supplementation (45).

Indeed, insulin affects the androgenic state not only directly by interfering with metabolism of ovarian androgens, but also indirectly by decreasing circulating SHBG levels (32). SHBG is a protein that binds to testosterone, making it unavailable to target tissues. Higher levels of SHBG lead to lower bioavailability of testosterone, thus minimizing the hyperandrogenic features. Furthermore, SHBG appears to be a potentially valuable marker of IR in PCOS (76). Interventions improving insulin sensitivity and reducing circulating insulin, such as metformin, troglitazone and pioglitazone, have been shown to reduce circulating testosterone and increase serum SHBG levels $(77,78,79)$. Clinical studies suggested that metformin, used as an antidiabetic drug, may improve insulin sensitivity in obese women with PCOS by restoring an inositol-based signaling $(61,80)$. Nonetheless, these drugs have been reported to be associated with adverse effects (81). Indeed, metformin, the most common insulin-sensitizing agent for PCOS (82, $83,84,85,86)$, significantly induces nausea, abdominal distress and diarrhea, thereby reducing patients' compliance $(87,88)$. MI is generally well tolerated across the range of therapeutic dosages (89), with the exception of minor side effects reported at higher concentration. Interestingly, in this meta-analysis, the tolerability profile of MI is considered to be quite agreeable. Among the studies, only Gerli and coworkers reported side effects on the dosage regimen commonly used (49).

The growing interest toward the clinical effects of inositols is witnessed by the recent meta-analysis which demonstrated how this supplement is effective in promoting ovulation in patients with PCOS (90). In conclusion, the present meta-analysis of nine RCTs revealed that $\mathrm{MI}$ alone or combined with DCI improves the metabolic profile of women with PCOS, also increasing SHBG when supplementation lasted at least 24 weeks.

\section{Declaration of interest}

Unfer V and Orrù B are employees at Lo.Li. Pharma, Rome, Italy. Giordani $B$ has received compensation as a consultant for the meta-analysis from Lo.Li. Pharma. The other authors have no conflicts of interest.

\section{Funding}

This review did not receive any specific grant from any funding agency in the public or not-for-profit sector.

\section{References}

1 Bizzarri M, Fuso A, Dinicola S, Cucina A \& Bevilacqua A. Pharmacodynamics and pharmacokinetics of inositol(s) in health and disease. Expert Opinion on Drug Metabolism and Toxicology 2016 12 1181-1196. (doi:10.1080/17425255.2016.1206887)

2 Di Paolo G \& De Camilli P. Phosphoinositides in cell regulation and membrane dynamics. Nature 2006443 651-657. (doi:10.1038/ nature05185)

3 Paul C, Laganà AS, Maniglio P, Triolo O \& Brady DM. Inositol's and other nutraceuticals' synergistic actions counteract insulin resistance in polycystic ovarian syndrome and metabolic syndrome: state-ofthe-art and future perspectives. Gynecological Endocrinology 201632 431-438. (doi:10.3109/09513590.2016.1144741)

4 Giordano D, Corrado F, Santamaria A, Quattrone S, Pintaudi B, Di Benedetto A \& D'Anna R. Effects of myo-inositol supplementation in postmenopausal women with metabolic syndrome: a perspective, randomized, placebo-controlled study. Menopause 201118 102-104. (doi:10.1097/gme.0b013e3181e8e1b1)

5 Santamaria A, Giordano D, Corrado F, Pintaudi B, Interdonato ML, Di Vieste G, Di Benedetto A \& D'Anna R. One-year effects of myoinositol supplementation in postmenopausal women with metabolic syndrome. Climacteric 201215 490-495. (doi:10.3109/13697137.201 1.631063)

6 Celentano C, Matarrelli B, Mattei PA, Pavone G, Vitacolonna E \& Liberati M. Myo-inositol supplementation to prevent gestational diabetes mellitus. Current Diabetes Reports 201616 30. (doi:10.1007/ s11892-016-0726-6)

7 D'Anna R, Di Benedetto A, Scilipoti A, Santamaria A, Interdonato ML, Petrella E, Neri I, Pintaudi B, Corrado F \& Facchinetti F. Myo-inositol supplementation for prevention of gestational diabetes in obese pregnant women: a randomized controlled trial. Obstetrics and Gynecology 2015126 310-315. (doi:10.1097/aog.0000000000000958)

8 D'Anna R, Scilipoti A, Giordano D, Caruso C, Cannata ML, Interdonato ML, Corrado F \& Di Benedetto A. Myo-inositol supplementation and onset of gestational diabetes mellitus in pregnant women with a family history of type 2 diabetes: a prospective, randomized, placebo-controlled study. Diabetes Care 201336 854-857. (doi:10.2337/dc12-1371)

9 Santamaria A, Di Benedetto A, Petrella E, Pintaudi B, Corrado F, D'Anna R, Neri I \& Facchinetti F. Myo-inositol may prevent gestational diabetes onset in overweight women: a randomized, controlled trial. Journal of Maternal-Fetal and Neonatal Medicine 2015 19 1-4. (doi:10.3109/14767058.2015.1121478)

10 Zheng X, Liu Z, Zhang Y, Lin Y, Song J, Zheng L \& Lin S. Relationship between myo-inositol supplementary and gestational diabetes mellitus: a meta-analysis. Medicine 201594 e1604. (doi:10.1097/ MD.0000000000001604)

11 Genazzani AD. Inositol as putative integrative treatment for PCOS. Reproductive BioMedicine Online 201633 770-780. (doi:10.1016/j. rbmo.2016.08.024)

12 Unfer V, Carlomagno G, Dante G \& Facchinetti F. Effects of myoinositol in women with PCOS: a systematic review of randomized

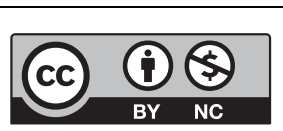

This work is licensed under a Creative Commons Attribution-NonCommercial 4.0 International License. 
controlled trials. Gynecological Endocrinology 201228 509-515. (doi:10.3109/09513590.2011.650660)

13 Unfer V, Nestler JE, Kamenov ZA, Prapas N \& Facchinetti F. Effects of inositol(s) in women with PCOS: a systematic review of randomized controlled trials. International Journal of Endocrinology 20162016 1-12. (doi:10.1155/2016/1849162)

14 Azziz R, Woods KS, Reyna R, Key TJ, Knochenhauer ES \& Yildiz BO. The prevalence and features of the polycystic ovary syndrome in an unselected population. Journal of Clinical Endocrinology and Metabolism 200489 2745-2749. (doi:10.1210/jc.2003-032046)

15 DeUgarte CM, Bartolucci AA \& Azziz R. Prevalence of insulin resistance in the polycystic ovary syndrome using the homeostasis model assessment. Fertility and Sterility 200583 1454-1460. (doi:10.1016/j.fertnstert.2004.11.070)

16 Laven JSE, Mulders AGMGJ, Santbrink EJP van, Eijkemans MJC \& Fauser BCJM. PCOS: backgrounds, evidence and problems in diagnosing the syndrome. International Congress Series 20051279 10-15. (doi:10.1016/j.ics.2005.01.002)

17 Diamanti-Kandarakis E. Polycystic ovarian syndrome: pathophysiology, molecular aspects and clinical implications. Expert Reviews in Molecular Medicine 200810 e3. (doi:10.1017/ S1462399408000598)

18 Lim SS, Davies MJ, Norman RJ \& Moran LJ. Overweight, obesity and central obesity in women with polycystic ovary syndrome: a systematic review and meta-analysis. Human Reproduction Update 201218 618-637. (doi:10.1093/humupd/dms030)

19 Vrbikova J \& Hainer V. Obesity and polycystic ovary syndrome. Obesity Facts 20092 26-35. (doi:10.1159/000194971)

20 Palomba S, Santagni S, Falbo A, Battista G \& Sala L. Complications and challenges associated with polycystic ovary syndrome: current perspectives. International Journal of Women's Health 20157 745-763. (doi:10.2147/IJWH.S70314)

21 Qin JZ, Pang LH, Li MJ, Fan XJ, Huang RD \& Chen HY. Obstetric complications in women with polycystic ovary syndrome: a systematic review and meta-analysis. Reproductive Biology and Endocrinology 201311 56. (doi:10.1186/1477-7827-11-56)

22 Ehrmann DA, Barnes RB, Rosenfield RL, Cavaghan MK \& Imperial J. Prevalence of impaired glucose tolerance and diabetes in women with polycystic ovary syndrome. Diabetes Care 199922 141-146. (doi:10.2337/diacare.22.1.141)

23 Legro RS, Kunselman AR, Dodson WC \& Dunaif A. Prevalence and predictors of risk for type 2 diabetes mellitus and impaired glucose tolerance in polycystic ovary syndrome: a prospective, controlled study in 254 affected women. Journal of Clinical Endocrinology and Metabolism 199984 165-169. (doi:10.1210/jcem.84.1.5393)

24 Dunaif A, Graf M, Mandeli J, Laumas V \& Dobrjansky A. Characterization of groups of hyperaiidrogenic women with acanthosis nigricans, impaired glucose tolerance, and/or hyperinsulinemia. Journal of Clinical Endocrinology and Metabolism 198765 499-507. (doi:10.1210/jcem-65-3-499)

25 Cattrall FR \& Healy DL. Long-term metabolic, cardiovascular and neoplastic risks with polycystic ovary syndrome. Best Practice and Research: Clinical Obstetrics and Gynaecology 200418 803-812. (doi:10.1016/j.bpobgyn.2004.05.005)

26 de Groot PCM, Dekkers OM, Romijn JA, Dieben SWM \& Helmerhorst FM. PCOS, coronary heart disease, stroke and the influence of obesity: a systematic review and meta-analysis. Human Reproduction Update 201117 495-500. (doi:10.1093/humupd/dmr001)

27 Rizzo M, Berneis K, Spinas G, Rini GB \& Carmina E. Long-term consequences of polycystic ovary syndrome on cardiovascular risk. Fertility and Sterility 200991 1563-1567. (doi:10.1016/j. fertnstert.2008.09.070)

28 Hadjiconstantinou M, Mani H, Patel N, Levy M, Davies M, Khunti K $\&$ Stone M. Understanding and supporting women with polycystic ovary syndrome: a qualitative study in an ethnically diverse UK sample. Endocrine Connections 20176 323-330. (doi:10.1530/ EC-17-0053)

29 Barry JA, Kuczmierczyk AR \& Hardiman PJ. Anxiety and depression in polycystic ovary syndrome: a systematic review and meta-analysis. Human Reproduction 201126 2442-2451. (doi:10.1093/humrep/der197)

30 Dokras A, Clifton S, Futterweit W \& Wild R. Increased prevalence of anxiety symptoms in women with polycystic ovary syndrome: systematic review and meta-analysis. Fertility and Sterility 201297 225-230. (doi:10.1016/j.fertnstert.2011.10.022)

31 Chittenden BG, Fullerton G, Maheshwari A \& Bhattacharya S. Polycystic ovary syndrome and the risk of gynaecological cancer: a systematic review. Reproductive Biomedicine Online 200919 398-405. (doi:10.1016/S1472-6483(10)60175-7)

32 Nestler JE. Insulin regulation of human ovarian androgens. Human Reproduction 199712 (Supplement 1) 53-62. (doi:10.1093/ humrep/12.suppl_1.53)

33 Nestler JE \& Unfer V. Reflections on inositol(s) for PCOS therapy: steps toward success. Gynecological Endocrinology 201531 501-505. (doi:10.3109/09513590.2015.1054802)

34 Facchinetti F, Bizzarri M, Benvenga S, D'Anna R, Lanzone A, Soulage C, Di Renzo GC, Hod M, Cavalli P, Chiu TT, et al. Results from the international consensus conference on myo-inositol and D-chiroinositol in obstetrics and gynecology: the link between metabolic syndrome and PCOS. European Journal of Obstetrics Gynecology and Reproductive Biology 2015195 72-76. (doi:10.1016/j.ejogrb.2015.09.024)

35 Muscogiuri G, Palomba S, Laganà AS \& Orio F. Current insights into inositol isoforms, mediterranean and ketogenic diets for polycystic ovary syndrome: from bench to bedside. Current Pharmaceutical Design 201622 5554-5557. (doi:10.2174/1381612822666160720160634)

36 Showell MG, Mackenzie-Proctor R, Jordan V, Hodgson R, Brown J \& Farquhar C. Inositol for subfertile women with polycystic ovary syndrome (Protocol). Cochrane Database of Systematic Reviews 20169 CD012378. (doi:10.1002/14651858.CD012378)

37 Green S, Higgins JPT, Alderson P, Clarke M, Mulrow CD \& Oxman AD. Cochrane handbook for systematic reviews of interventions. 5.0.2. In The Cochrane Collaboration. Chichester, UK: John Wiley \& Sons Ltd, 2009.

38 Moher D, Liberati A, Tetzlaff J, Altman DG \& The PRISMA Group. Preferred reporting items for systematic reviews and meta analyses: the PRISMA Statement. PLoS Medicine 20096 e1000097. (doi:10.1371/journal.pmed1000097)

39 Fruzzetti F, Perini D, Russo M, Bucci F \& Gadducci A. Comparison of two insulin sensitizers, metformin and myo-inositol, in women with polycystic ovary syndrome (PCOS). Gynecological Endocrinology 2016 33 39-42. (doi:10.1080/09513590.2016.1236078)

40 Gerli S, Mignosa M \& Di Renzo G. Effects of inositol on ovarian function and metabolic factors in women with PCOS: a randomized double blind placebo-controlled trial. European Review for Medical and Pharmacological Sciences 20037 151-159.

41 Genazzani AD, Santagni S, Ricchieri F, Campedelli A, Rattighieri E, Chierchia E, Marini G, Despini G, Prati A \& Simoncini T. Myo-inositol modulates insulin and luteinizing hormone secretion in normal weight patients with polycystic ovary syndrome. Journal of Obstetrics and Gynaecology Research 201440 1353-1360. (doi:10.1111/jog.12319)

42 Minozzi M, Costantino D, Guaraldi C \& Unfer V. The effect of a combination therapy with myo-inositol and a combined oral contraceptive pill versus a combined oral contraceptive pill alone on metabolic, endocrine, and clinical parameters in polycystic ovary syndrome. Gynecological Endocrinology 201127 920-924. (doi:10.3109 /09513590.2011.564685)

43 Genazzani AD, Prati A, Santagni S, Ricchieri F, Chierchia E, Rattighieri E, Campedelli A, Simoncini T \& Artini PG. Differential insulin response to myo-inositol administration in obese polycystic ovary syndrome patients. Gynecological Endocrinology 201228 969-973. (doi:10.3109/09513590.2012.685205) http://www.endocrineconnections.org

DOI: 10.1530/EC-17-0243 (c) 2017 The authors

Published by Bioscientifica Ltd

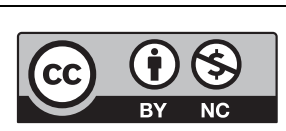

This work is licensed under a Creative Commons Attribution-NonCommercial 4.0 International License. 
44 Minozzi M, D'Andrea G \& Unfer V. Treatment of hirsutism with myo-inositol: a prospective clinical study. Reproductive BioMedicine Online 200817 579-582. (doi:10.1016/S1472-6483(10)60248-9)

45 Zacchè MM, Caputo L, Filippis S, Zacchè G, Dindelli M \& Ferrari A. Efficacy of myo-inositol in the treatment of cutaneous disorders in young women with polycystic ovary syndrome. Gynecological Endocrinology 200925 508-513. (doi:10.1080/09513590903015544)

46 Artini PG, Di Berardino OM, Papini F, Genazzani AD, Simi G, Ruggiero M \& Cela V. Endocrine and clinical effects of myo-inositol administration in polycystic ovary syndrome. A randomized study. Gynecological Endocrinology 201329 375-379. (doi:10.3109/09513590. 2012.743020)

47 Costantino D, Minozzi G, Minozzi E \& Guaraldi C. Metabolic and hormonal effects of myo-inositol in women with polycystic ovary syndrome: a double-blind trial. European Review for Medical and Pharmacological Sciences 200913 105-110.

48 Genazzani AD, Lanzoni C, Ricchieri F \& Jasonni VM. Myoinositol administration positively affects hyperinsulinemia and hormonal parameters in overweight patients with polycystic ovary syndrome. Gynecological Endocrinology 200824 139-144. (doi:10.1080/09513590801893232)

49 Gerli S, Papaleo E, Ferrari A \& Di Renzo GC. Randomized, double blind placebo-controlled trial: effects of myo-inositol on ovarian function and metabolic factors in women with PCOS. European Review for Medical and Pharmacological Sciences 200711 347-354.

50 Pizzo A, Laganà AS \& Barbaro L. Comparison between effects of myo-inositol and D-chiro-inositol on ovarian function and metabolic factors in women with PCOS. Gynecological Endocrinology 201430 205-208. (doi:10.3109/09513590.2013.860120)

51 Nordio M \& Proietti E. The combined therapy with myo-inositol and D-chiro-inositol reduces the risk of metabolic disease in PCOS overweight patients compared to myo-inositol supplementation alone. European Review for Medical and Pharmacological Sciences 2012 16 575-581.

52 Benelli E, Del Ghianda S, Cosmo C Di \& Tonacchera M. A combined therapy with myo-inositol and D-chiro-inositol improves endocrine parameters and insulin resistance in PCOS young overweight women. International Journal of Endocrinology 20162016. (doi:10.1155/2016/3204083)

53 Pkhaladze L, Barbakadze L \& Kvashilava N. Myo-inositol in the treatment of teenagers affected by PCOS. International Journal of Endocrinology 2016 2016. (doi:10.1155/2016/1473612).

54 Ozay AC, Emekci Ozay O, Okyay RE, Cagliyan E, Kume T \& Gulekli B. Different effects of myo-inositol plus folic acid versus combined oral treatment on androgen levels in PCOS women. International Journal of Endocrinology 20162016 (doi:10.1155/2016/3206872)

55 The Rotterdam ESHRE/ASRM Sponsored PCOS Consensus Workshop Group. Revised 2003 consensus on diagnostic criteria and long-term health risks related to polycystic ovary syndrome (PCOS). Human Reproduction 200419 41-47. (doi:10.1093/humrep/deh098)

56 Adams J, Polson DW \& Franks S. Prevalence of polycystic ovaries in women with anovulation and idiopathic hirsutism. BMJ 1986293 355-359. (doi:10.1136/bmj.293.6543.355)

57 Sun TH, Heimark DB, Nguygen T, Nadler JL \& Larner J. Both myoinositol to chiro-inositol epimerase activities and chiro-inositol to myo-inositol ratios are decreased in tissues of GK type 2 diabetic rats compared to Wistar controls. Biochemical and Biophysical Research Communications 2002293 1092-1098. (doi:10.1016/S0006291X(02)00313-3)

58 Larner J. D-Chiro-inositol - its functional role in insulin action and its deficit in insulin resistance. International Journal of Experimental Diabetes Research 20023 47-60. (doi:10.1080/15604280212528)

59 Unfer V, Carlomagno G, Papaleo E, Vailati S, Candiani M \& Baillargeon JP. Hyperinsulinemia alters myoinositol to D-chiroinositol ratio in the follicular fluid of patients with PCOS. Reproductive Sciences 201421 854-858. (doi:10.1177/1933719113518985)

60 Heimark D, McAllister J \& Larner J. Decreased myo-inositol to chiroinositol (M/C) ratios and increased M/C epimerase activity in PCOS theca cells demonstrate increased insulin sensitivity compared to controls. Endocrine Journal 201461 111-117. (doi:10.1507/endocrj. EJ13-0423)

61 Laganà AS, Barbaro L \& Pizzo A. Evaluation of ovarian function and metabolic factors in women affected by polycystic ovary syndrome after treatment with D-chiro-inositol. Archives of Gynecology and Obstetrics 2015291 1181-1186. (doi:10.1007/s00404-014-3552-6)

62 Baillargeon JP, Diamanti-Kandarakis E, Ostlund RE, Apridonidze T, Iuorno MJ \& Nestler JE. Altered D-chiro-inositol urinary clearance in women with polycystic ovary syndrome. Diabetes Care 200629 300-305. (doi:10.2337/diacare.29.02.06.dc05-1070)

63 Muscogiuri G, Palomba S, Laganà AS \& Orio F. Inositols in the treatment of insulin-mediated diseases. International Journal of Endocrinology 20162016 3058393. (doi:10.1155/2016/3058393)

64 Baillargeon JP \& Nestler JE. Commentary: polycystic ovary syndrome: a syndrome of ovarian hypersensitivity to insulin? Journal of Clinical Endocrinology and Metabolism 200691 22-24. (doi:10.1210/ jc.2005-1804)

65 Harwood K, Vuguin P \& DiMartino-Nardi J. Current approaches to the diagnosis and treatment of polycystic ovarian syndrome in youth. Hormone Research 200768 209-217. (doi:10.1159/000101538)

66 Matalliotakis I, Kourtis A, Koukoura O \& Panidis D. Polycystic ovary syndrome: etiology and pathogenesis. Archives of Gynecology and Obstetrics 2006274 187-197. (doi:10.1007/s00404-006-0171-x)

67 Rice S, Christoforidis N, Gadd C, Nikolaou D, Seyani L, Donaldson A, Margara R, Hardy K \& Franks S. Impaired insulin-dependent glucose metabolism in granulosa-lutein cells from anovulatory women with polycystic ovaries. Human Reproduction 200520 373-381. (doi:10.1093/humrep/deh609)

68 Unfer V, Carlomagno G, Rizzo P, Raffone E \& Roseff S. Myo-inositol rather than D-chiro-inositol is able to improve oocyte quality in intracytoplasmic sperm injection cycles. A prospective, controlled, randomized trial. European Review for Medical and Pharmacological Sciences 201115 452-457.

69 Papaleo E, Unfer V, Baillargeon JP, Fusi F, Occhi F \& De Santis L. Myo-inositol may improve oocyte quality in intracytoplasmic sperm injection cycles. A prospective, controlled, randomized trial. Fertility and Sterility 200991 1750-1754. (doi:10.1016/j.fertnstert.2008.01.088)

70 Carlomagno G, Unfer V \& Roseff S. The D-chiro-inositol paradox in the ovary. Fertility and Sterility 201195 2515-2516. (doi:10.1016/j. fertnstert.2011.05.027)

71 Isabella R \& Raffone E. Does ovary need D-chiro-inositol? Journal of Ovarian Research 20125 14. (doi:10.1186/1757-2215-5-14)

72 Laganà AS, Sapia F, La Rosa VL \& Vitale SG. Comment on 'inositols: from physiology to rational therapy in gynecological clinical practice'. Expert Opinion on Drug Metabolism and Toxicology 201612 1527. (doi:10.1080/17425255.2016.1248598)

73 Nestler JE, Clore JN \& Blackard WG. The central role of obesity (hyperinsulinemia) in the pathogenesis of the polycystic ovary syndrome. American Journal of Obstetrics and Gynecology 1989161 1095-1097. (doi:10.1016/0002-9378(89)90640-6)

74 Nestler JE. Role of hyperinsulinemia in the pathogenesis of the polycystic ovary syndrome, and its clinical implications. Seminars in Reproductive Endocrinology 199715 111-122. (doi:10.1055/s-2007-414 1016294).

75 Marshall JCAD. All women with PCOS should be treated for insulin resistance. Fertility and Sterility 201297 18-22. (doi:10.1016/j. fertnstert.2011.11.036)

76 Cassar S, Misso ML, Hopkins WG, Shaw CS, Teede HJ \& Stepto NK. Insulin resistance in polycystic ovary syndrome: a systematic review and meta-analysis of euglycaemic-hyperinsulinaemic clamp studies. http://www.endocrineconnections.org

DOI: 10.1530/EC-17-0243
(C) 2017 The authors Published by Bioscientifica Ltd

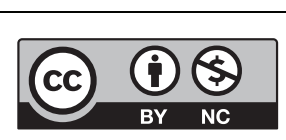

This work is licensed under a Creative Commons Attribution-NonCommercial 4.0 International License. 
Humam Reproduction 201631 2619-2631. (doi:10.1093/humrep/ dew243)

77 Pasquali R \& Gambineri A. Insulin-sensitizing agents in polycystic ovary syndrome. European Journal of Endocrinology $2006 \mathbf{1 5 4}$ 763-775. (doi:10.1530/eje.1.02156)

78 Lord JM, Flight IHK \& Norman RJ. Metformin in polycystic ovary syndrome: systematic review and meta-analysis. BMJ $2003 \mathbf{3 2 7}$ 951-953. (doi:10.1136/bmj.327.7421.951)

79 Genazzani AD, Battaglia C, Malavasi B, Strucchi C, Tortolani F \& Gamba O. Metformin administration modulates and restores luteinizing hormone spontaneous episodic secretion and ovarian function in nonobese patients with polycystic ovary syndrome. Fertility and Sterility 200481 114-119. (doi:10.1016/j. fertnstert.2003.05.020)

80 Baillargeon JP, Iuorno MJ, Jakubowicz DJ, Apridonidze T, He N \& Nestler JE. Metformin therapy increases insulin-stimulated release of D-chiro-inositol-containing inositolphosphoglycan mediator in women with polycystic ovary syndrome. Journal of Clinical Endocrinology and Metabolism 200489 242-249. (doi:10.1210/jc.2003-030437)

81 Nieuwenhuis-Ruifrok AE, Kuchenbecker WKH, Hoek A, Middleton P $\&$ Norman RJ. Insulin sensitizing drugs for weight loss in women of reproductive age who are overweight or obese: systematic review and meta-analysis. Human Reproduction Update 200915 57-68. (doi:10.1093/humupd/dmn043)

82 Lord JM, Flight IHK \& Norman RJ. Insulin-sensitising drugs (metformin, troglitazone, rosiglitazone, pioglitazone, D-chiroinositol) for polycystic ovary syndrome. Cochrane Database of Systematic Reviews 20033 CD003053. (doi:10.1002/14651858.
83 Lashen $\mathrm{H}$. Role of metformin in the management of polycystic ovary syndrome. Therapeutic Advances in Endocrinology and Metabolism 2010 1 117-128. (doi:10.1177/2042018810380215)

84 Palomba S, Falbo A, Russo T, Orio F, Tollino A \& Zullo F. Role of metformin in patients with polycystic ovary syndrome: the state of the art. Minerva Ginecologica 200860 77-82.

85 Johnson NP. Metformin use in women with polycystic ovary syndrome. Annals of Translational Medicine 20142 56. (doi:10.3978/j. issn.2305-5839.2014.04.15)

86 Mathur R, Alexander CJ, Yano J, Trivax B \& Azziz R. Use of metformin in polycystic ovary syndrome. American Journal of Obstetrics and Gynecology 2008199 596-609. (doi:10.1016/j. ajog.2008.09.010)

87 Naderpoor N, Shorakae S, Courten B De, Misso ML, Moran LJ \& Teede HJ. Metformin and lifestyle modification in polycysticovary syndrome: systematic review and meta-analysis. Human Reproduction Update 201521 560-574. (doi:10.1093/humupd/dmv025)

88 Misso ML, Costello MF, Garrubba M, Wong J, Hart R, Rombauts L, Melder AM, Norman RJ \& Teede HJ. Metformin versus clomiphene citrate for infertility in non-obese women with polycystic ovary syndrome: a systematic review and meta-analysis. Human Reproduction Update 201319 2-11. (doi:10.1093/humupd/dms036)

89 Carlomagno G \& Unfer V. Inositol safety: clinical evidences. European Review for Medical and Pharmacological Sciences 201115 931-936.

90 Pundir J, Psaroudakis D, Savnur P, Bhide P, Sabatini L, Teede H, Coomarasamy A \& Thangaratinam S. Inositol treatment of anovulation in women with polycystic ovary syndrome: a metaanalysis of randomised trials. British Journal of Obstetrics and Gynaecology 2017 [in press]. (doi:10.1111/1471-0528.14754)

Received in final form 12 September 2017

Accepted 20 September 2017 http://www.endocrineconnections.org DOI: 10.1530/EC-17-0243 (c) 2017 The authors Published by Bioscientifica Ltd

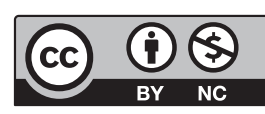

This work is licensed under a Creative Commons Attribution-NonCommercial 4.0 International License. 